\title{
Detection of the argonaute protein Ago2 and microRNAs in the RNA induced silencing complex (RISC) using a monoclonal antibody
}

K. Ikeda

M. Satoh

Kaleb M. Pauley

CedarvilleUniversity, kpauley@cedarville.edu

M.J. Fritzler

W. H. Reeves

See next page for additional authors

Follow this and additional works at: http://digitalcommons.cedarville.edu/ science_and_mathematics_publications

Part of the Life Sciences Commons, and the Oral Biology and Oral Pathology Commons

\section{Recommended Citation}

Ikeda, K.; Satoh, M.; Pauley, Kaleb M.; Fritzler, M. J.; Reeves, W. H.; and Chan, E. K., "Detection of the argonaute protein Ago2 and microRNAs in the RNA induced silencing complex (RISC) using a monoclonal antibody" (2006). Science and Mathematics Faculty Publications. 197.

http://digitalcommons.cedarville.edu/science_and_mathematics_publications/197

This Article is brought to you for free and open access by DigitalCommons@Cedarville, a service of the Centennial Library. It has been accepted for inclusion in Science and Mathematics Faculty 
Authors

K. Ikeda, M. Satoh, Kaleb M. Pauley, M. J. Fritzler, W. H. Reeves, and E. K. Chan 


\title{
Research paper
}

\section{Detection of the argonaute protein Ago2 and microRNAs in the RNA induced silencing complex (RISC) using a monoclonal antibody}

\author{
Keigo Ikeda ${ }^{\mathrm{a}}$, Minoru Satoh ${ }^{\mathrm{b}}$, Kaleb M. Pauley ${ }^{\mathrm{a}}$, Marvin J. Fritzler ${ }^{\mathrm{c}}$, \\ Westley H. Reeves ${ }^{b}$, Edward K.L. Chan ${ }^{\text {a,* }}$ \\ a Department of Oral Biology, University of Florida, 1600 SW Archer Rd., Gainesville, FL 32610-0424, USA \\ ${ }^{\mathrm{b}}$ Division of Rheumatology and Clinical Immunology, Department of Medicine and Department of Pathology, Immunology, \\ and Laboratory Medicine, University of Florida, Gainesville, FL, USA \\ ${ }^{\mathrm{c}}$ Faculty of Medicine, University of Calgary, Calgary, AB, Canada
}

Received 1 July 2006; received in revised form 20 August 2006; accepted 7 September 2006

Available online 4 October 2006

\begin{abstract}
MicroRNAs (miRNAs) are short RNA molecules responsible for post-transcriptional gene silencing by the degradation or translational inhibition of their target messenger RNAs (mRNAs). This process of gene silencing, known as RNA interference (RNAi), is mediated by highly conserved Argonaute (Ago) proteins which are the key components of the RNA induced silencing complex (RISC). In humans, Ago2 is responsible for the endonuclease cleavage of targeted mRNA and it interacts with the mRNAbinding protein GW182, which is a marker for cytoplasmic foci referred to as GW bodies (GWBs). We demonstrated that the antiAgo2 monoclonal antibody 4F9 recognized GWBs in a cell cycle dependent manner and was capable of capturing miRNAs associated with Ago2. Since Ago2 protein is the effector protein of RNAi, anti-Ago2 monoclonal antibody may be useful in capturing functional miRNAs.
\end{abstract}

(C) 2006 Elsevier B.V. All rights reserved.

Keywords: Argonaut protein; GW182; GW bodies; Monoclonal antibody; MicroRNA; P body; RNA interference

Abbreviations: Ago, argonaute; ELISA, enzyme-linked immunosorbent assay; GWBs, GW bodies; IP, immunoprecipitation; IIF, indirect immunofluorescence; IMS, immune mouse sera; $\mathrm{kDa}$, kiloDalton; mRNA, messenger RNA; miRNA, microRNA; miR-16, microRNA-16; miR-24, microRNA-24; NMS, normal mouse sera; PBS, phosphate buffered saline; RT-PCR, reverse transcriptasepolymerase chain reaction; RISC, RNA induced silencing complex; RNAi, RNA interference.

* Corresponding author. Tel.: +1 352392 6190; fax: +1 352392 4620 .

E-mail address: echan@ufl.edu (E.K.L. Chan).

\section{Introduction}

Post-transcriptional gene silencing or RNA interference (RNAi) is a crucial regulatory pathway of eukaryotic gene expression that occurs in a wide variety of organisms (Meister and Tuschl, 2004). One key player in this pathway is the microRNAs (miRNAs), which are 21 to 24 nucleotide long RNA molecules that bind to partially complementary sequences within the $3^{\prime}-$ untranslated region of target mRNAs leading to translation suppression and/or degradation. miRNAs are encoded in the genome and are transcribed into primary miRNA (pri-miRNA) molecules. These pri-miRNAs are 
processed in the nucleus by the RNase III enzyme Drosha and its partner protein DGCR8 (Gregory et al., 2004). The resulting miRNA precursors (pre-miRNAs) are then transported to the cytoplasm by Exportin-5 (Lund et al., 2004). Finally, pre-miRNAs are further processed by the cytoplasmic RNase III enzyme Dicer, and the resulting mature miRNAs enter the RISC. The key components of the RISC complex are Argonaute (Ago) proteins with molecular masses of approximately $100 \mathrm{kDa}$ and containing PAZ and PIWI domains (Carmell et al., 2002; Sasaki et al., 2003). Four of these, Ago1 to Ago4, have been demonstrated to associate with miRNAs in humans (Liu et al., 2005b). However, only Ago2 has been demonstrated to possess the activity of miRNA-guided mRNA cleavage or translational inhibition (Meister et al., 2004). Thus, Ago are the key proteins that mediate miRNA function and the significance for "free" or non-Ago bound miRNA subsets is unclear. Furthermore, Ago 2 has been shown to associate with GW182, the $182 \mathrm{kDa}$ mRNAbinding protein (Eystathioy et al., 2002) and a critical component of GW bodies (GWBs) (Jakymiw et al., 2005). GWBs are proposed to be cytoplasmic sites for mRNA storage and degradation (Eystathioy et al., 2002), and possible sites for RNAi in mammalian cells (Jakymiw et al., 2005). GW182 is also reported to be required for efficient miRNA mediated repression of mRNA (Liu et al., 2005a). Our recent report showed that the formation of GWBs is a consequence of miRNA genesis based on the observation that the inhibition of miRNA maturation led to disassembly of GWBs (Pauley et al., 2006). In this study, we describe a novel Ago2 monoclonal antibody 4F9 capable of capturing Ago-associated miRNAs in mammalian cells. This monoclonal antibody may be useful in characterizing functional subsets of miRNA in different systems.

\section{Materials and methods}

\subsection{Purified recombinant Ago2 protein}

A human Ago2 cDNA encoding the full length of the Ago2 protein was subcloned into pDEST ${ }^{\mathrm{TM}} 17$ (Invitrogen $^{\mathrm{TM}}$, Carlsbad, CA, USA) expression vector. The recombinant protein was produced in Escherichia coli BL21 (DE3) and purified using $\mathrm{Ni}^{2+}$ affinity chromatography as per the manufacturer's instructions (Qiagen, Valencia, CA, USA). The soluble recombinant protein was subsequently used in the immunization protocol and enzyme-linked immunosorbent assay (ELISA) described below.

\subsection{Production of mouse monoclonal antibody to Ago2}

We have recently reported that anti-Ago2 autoantibodies are detected in a significant number of patients with autoantibodies to the $\mathrm{Su}$ antigen (Jakymiw et al., 2006). Anti-Su antibodies have also been described in mice treated with pristane (2,6,10,14-tetramethylpentade-cane, or TMPD). One of the major antigenic targets of anti-Su is Ago2 but there are other unidentified $\mathrm{Su}$ antigens including the $200 \mathrm{kDa}$ protein (Jakymiw et al., 2006). To generate anti-Ago 2 antibodies, BALB/cJ mice were intraperitoneally injected with $0.5 \mathrm{ml}$ pristane. Sera were collected 12 weeks later and screened for antiAgo2 antibody using an antigen-capture ELISA as described (Satoh et al., 1995). Anti-Ago2 positive mice were then given an intravenous booster injection of purified soluble recombinant Ago2 protein in phosphate buffered saline (PBS) three days prior to the harvest of spleen cells for hybridoma fusion. The hybridoma cells were cultured and selected using Dulbecco's modified Eagle's minimal essential medium that contained $15 \%$ horse serum and hypoxanthine-aminopterin-thymidine. The production of monoclonal antibodies to Ago2 was screened by ELISA and indirect immunofluorescence (IIF) as described below. These studies were approved by the institutional animal care and use committee of the University of Florida.

\subsection{Enzyme-linked immunosorbent assay}

Purified soluble recombinant Ago2 protein was diluted in PBS to a final concentration of $2 \mu \mathrm{g} / \mathrm{ml}$ and coated on MaxiSorp ${ }^{\mathrm{TM}}$ microtiter plates (Nunc ${ }^{\mathrm{TM}}$, Naperville, IL, USA). Undiluted hybridoma culture supernatants were initially screened and mouse antiAgo2 sera were diluted 1:1000 and used as positive control. Horseradish peroxidase-conjugated goat antimouse IgG (CALTAG ${ }^{\mathrm{TM}}$ Laboratories, Burlingame, CA, USA) was used at a dilution of 1:2000 and the optical density (OD) at $405 \mathrm{~nm}$ was obtained as described (Rubin, 1997).

\subsection{Immunoprecipitation (IP)}

Human K562 cells, HeLa cells, HEp-2 cells, and murine NIH-3T3 cells were metabolically labeled with $\left[{ }^{35} \mathrm{~S}\right]$-methionine (MP Biomedicals, Irvine, CA, USA), resuspended at $10^{7}$ cells $/ \mathrm{ml}$ in $500 \mathrm{mM} \mathrm{NaCl} \mathrm{NET} \mathrm{buffer}$ (500 mM NaCl, 2 mM EDTA, 50 mM Tris-HCl, pH 7.5) containing $0.3 \%$ Nonidet-P40 and Complete Protease Cocktail Inhibitors (Roche, Mannheim, Germany), sonicated for $60 \mathrm{~s}$, and cleared by centrifugation at 
$10,000 \times g$ for $10 \mathrm{~min}$. The full-length human Ago cDNAs (Agol: clone 30344513, GenBank BC063275: Ago2: pCMV-SPORT6 kindly provided by Dr. Tom Hobman, University of Alberta, Edmonton, AB, Canada: Ago3 clone CS0DB008YP10, GenBank AL522515; Ago4:clone 4373725, GenBank BF979532) were used as templates for in vitro transcription and translation (TnT ${ }^{\circledR}$, Promega, Madison, WI, USA) in the presence of $\left[{ }^{35} \mathrm{~S}\right]$-methionine as described (Jakymiw et al., 2006). In brief, IP of K562 cell extracts and in vitro translated products were used in IP reactions by combining $100 \mu \mathrm{l}$ of a 10\% Protein A-Sepharose CL-4B beads (Amersham Biosciences, Piscataway, NJ, USA) with $100 \mu \mathrm{l}$ of 4F9 culture supernatant or $5 \mu \mathrm{l}$ of sera, $500 \mathrm{mM} \mathrm{NaCl} \mathrm{NET}$ buffer containing $0.3 \% \mathrm{NP}-40$, and the individual radiolabeled proteins. After $1 \mathrm{~h}$ incubation at $4{ }^{\circ} \mathrm{C}$, the suspension was washed four times in $500 \mathrm{mM} \mathrm{NaCl}$ NET buffer containing NP-40, and eluted in $25 \mu 1$ sample buffer. For IP experiments involving TnT products, in vitro translated radiolabeled Luciferase protein was added to the IP mix to monitor the specificity of IP reactions. Immunoprecipitates were analyzed by $10 \%$ gel SDSPAGE followed by autoradiography (Jakymiw et al., 2006).

\subsection{Indirect immunofluorescence (IIF)}

HeLa or HEp-2 cells were cultured as monolayers, fixed in $4 \%$ paraformaldehyde in PBS ( $\mathrm{pH} 7.4$ ) for $10 \mathrm{~min}$, permeabilized in $0.1 \%$ Triton X-100 and $0.15 \%$ Saponin in PBS for $10 \mathrm{~min}$, incubated with mouse monoclonal or human antibodies, washed and subsequently detected by Alexa Fluor ${ }^{\circledR} 488$ or Cy3-con- jugated goat anti-IgG antibody appropriate for the species (Invitrogen, Eugene, OR, USA). All of the fixation, permeabilization and incubation with antibodies were performed on ice. Nuclei in the cell substrates were counterstained with 4',6-diamidino-2-phenylindole (DAPI) that was included in the VectaShield Hard Set Mounting Medium (Vector Laboratories, Burlingame, CA, USA). In addition, monoclonal antibodies were also analyzed on commercial HEp-2 cell slides (HEp2000, ImmunoConcepts, Sacramento, CA, USA). Rabbit antiphosphohistone $\mathrm{H} 3$ was obtained from Upstate Biotech (Charlottesville, VA, USA) and used at a dilution of 1:300 to monitor cells in late $\mathrm{S}$ and $\mathrm{G} 2$ phases. Images of fixed cells were obtained using $63 \times 1.4$ NA objectives on a Zeiss Axiovert 200M microscope. For 8-bit color images, pixel intensity levels were adjusted using Adobe Photoshop version 7.0 so that maximal and minimal values were 0 and 255 in each channel.

\subsection{MicroRNA RT-PCR assay}

RT-PCR was performed using $20 \mathrm{ng}$ of RNAs isolated from the Protein A Sepharose and antibody complexes, and HeLa cell extracts after IP as described above except using unlabeled cells. The RNAs were isolated from Protein A beads utilizing the mirVana miRNA Isolation Kit (Ambion, Austin, TX, USA) which was used according to the manufacture's protocol. RT-PCR was performed using the mirVana qRT-PCR miRNA Detection Kit (Ambion). Briefly, miRNAs were reverse transcribed by using miRNA RT Primer (Ambion) incubated at $37^{\circ} \mathrm{C}$ for $30 \mathrm{~min}$ and then $95^{\circ} \mathrm{C}$ for $10 \mathrm{~min}$. After the RT step, the miRNA cDNA was amplified using miRNA PCR
A

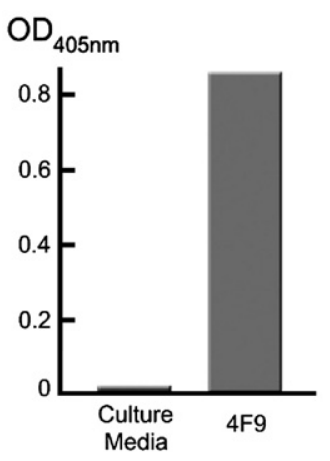

B

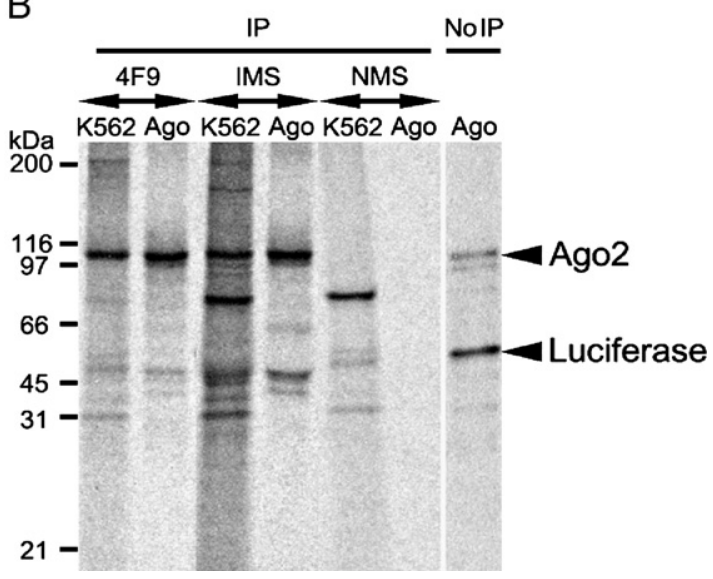

Fig. 1. Development of mouse monoclonal anti-Ago2 antibody 4F9. (A) ELISA reactivity of 4F9 with purified soluble recombinant Ago2 protein. (B) Representative immunoprecipitation analysis of 4F9 reactivity using K562 cell extracts (K562) and in vitro translation product of Ago2 recombinant protein (Ago) both labeled with $\left[{ }^{35} \mathrm{~S}\right]$-methionine. Immune mouse anti-Ago2 serum (IMS) is used for positive control and normal mouse serum (NMS) as negative control. 
primers with $3 \mathrm{~min}$ initial denaturation at $95{ }^{\circ} \mathrm{C}$, and followed by 30 cycles of $95{ }^{\circ} \mathrm{C}$ for $15 \mathrm{~s}$ and $60{ }^{\circ} \mathrm{C}$ for $30 \mathrm{~s}$. The PCR products were confirmed using a $3.5 \%$ high resolution agarose gel in Tris-Acetate-EDTA buffer stained with ethidium bromide.

\section{Results and discussion}

\subsection{Development of anti-Ago2 hybridoma from pristane treated mice}

Intraperitoneal injection of pristane into mice leads to autoantibody responses analogous to those described in some human systemic lupus erythematosus sera (Satoh and Reeves, 1994). Recently, we reported that pristane injected BALB/cJ mice produce anti-Ago2 autoantibodies and these autoantibodies are also detected in rheumatic disease sera (Jakymiw et al., 2006). To further support our initial findings, anti-Ago2 autoantibody positive mice were selected for hybridoma production and $\sim 800$ hybridoma clones were screened with recombinant Ago2 coated ELISA plates. A single

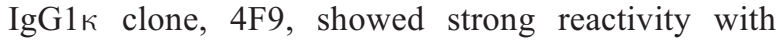
recombinant Ago2 by ELISA (Fig. 1A). Subcloning using standard limited dilution cloning was performed twice over a 3 month period.

\section{A}

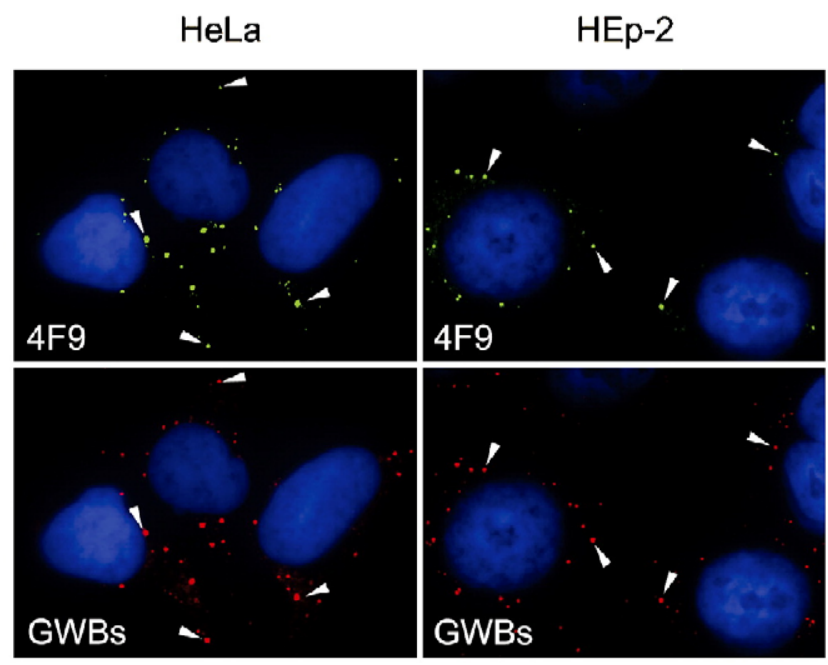

B
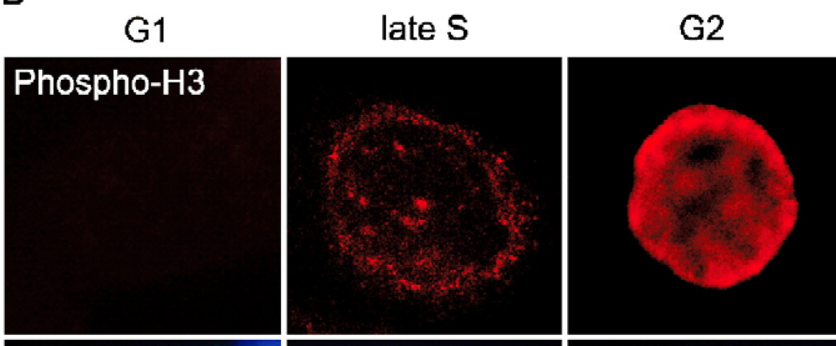

M
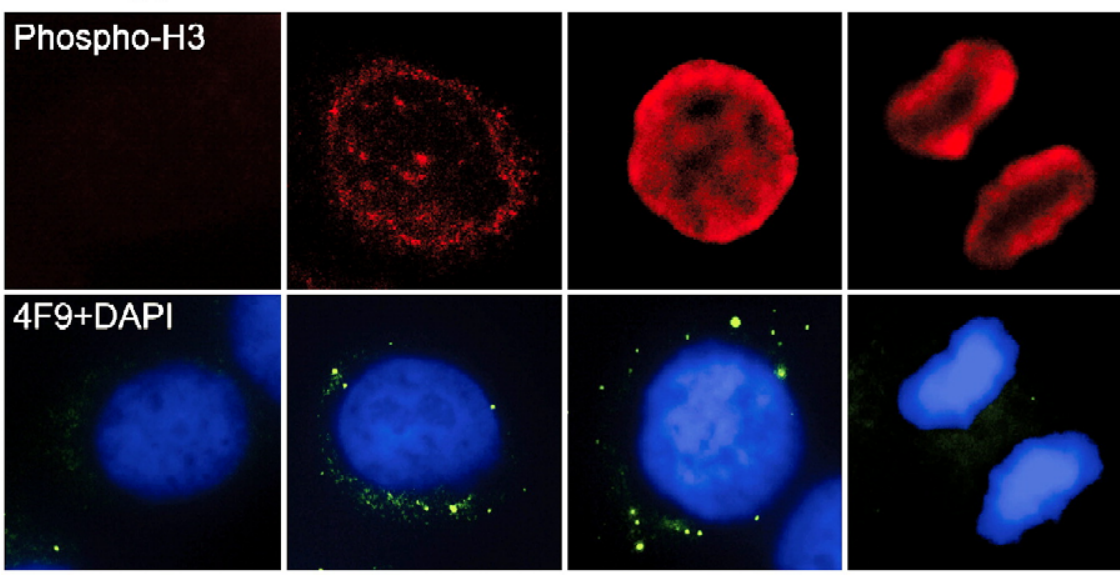

Fig. 2. Immunofluorescence analysis of 4F9. (A) Monoclonal 4F9 (green) recognized cytoplasmic foci identified as GW bodies (GWBs) by costaining with a human index serum known to contain antibodies to anti-Ago2 and GW182 (red). HeLa cells (left panels) were fixed as described in Methods. HEp-2 cells (right panels) were on commercially prepared slides (ImmunoConcepts Inc). Arrowheads show representative GWBs. (B) Monoclonal 4F9 showed staining of GWBs in a cell cycle dependent manner. HEp-2 cells were costained with 4F9 (green foci, bottom panels) and rabbit anti-phosphohistone H3 serum (red, top panels). 


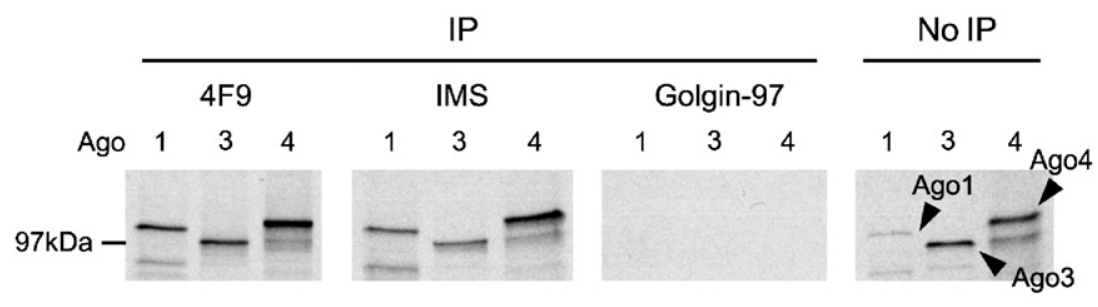

Fig. 3. Monoclonal 4F9 crossreacted with Ago1, Ago3 and Ago4. Immunoprecipitation analysis of 4F9 was performed using in vitro translation products of Ago1, 3 and 4 recombinant proteins labeled with $\left[{ }^{35} \mathrm{~S}\right]$-methionine. IMS and mouse anti-golgin-97 antibody were used as positive and negative control, respectively.

\subsection{F9 recognized a conserved conformational epitope}

To confirm that 4F9 recognized Ago2, IP was performed using $\mathrm{K} 562$ cell extracts and in vitro translated Ago2 protein both radiolabeled with $\left[{ }^{35} \mathrm{~S}\right]$ methionine. A $100 \mathrm{kDa}$ protein that comigrated with the in vitro translated Ago 2 protein as well as the positive control was IP by the immune mouse anti-Ago2 serum (IMS, Fig. 1B). In contrast, normal mouse serum (NMS) did not immunoprecipitate Ago2 from K562 cell extracts or in vitro translated Ago2. The inability of 4F9 and IMS to immunoprecipitate the in vitro translated Luciferase product also demonstrated the specificity of 4F9 and IMS for Ago2. Additionally, 4F9 immunoprecipitated Ago2 from radiolabeled HeLa, HEp-2 and NIH-3T3 cell extracts (data not shown). 4F9 showed very weak or no reactivity in western blot analysis using HeLa and HEp-2 cell extracts (data not shown). Furthermore, epitope mapping was attempted using sequential overlapping peptides of 15 amino acids spanning the full-length Ago2 protein synthesized on a membrane as previously described (Eystathioy et al., 2003). When 4F9 was applied to the membrane for immunoblotting, specific reactivity was not detected (data not shown). Additionally, no specific reactivity for either mouse or human anti-Ago2 sera was detected with the Ago 2 epitope mapping membrane. Interestingly, this lack of reactivity with denatured or linear epitopes exhibited by 4F9 is highly consistent with published data for human and mouse anti-Ago2 autoantibody (Satoh et al., 1994). Based on these observations, we concluded that $4 \mathrm{~F} 9$ recognized a conformational dependent epitope similar to autoantibody reported for Ago2.

\subsection{F9 recognized GWBs in a cell cycle dependent pattern}

4F9 recognized cytoplasmic foci identified as GWBs because there was costaining with a human index serum known to contain antibodies to $\mathrm{Ago} 2$ and GW182 (Fig. 2A); the latter is a marker protein for
GWBs. This staining pattern was confirmed using both HeLa cells fixed and permeabilized as described in Methods and the commercially prepared HEp-2 cells. To determine optimal fixation parameters, various fixation methods that included methanol, acetone/methanol, and ethanol were used but none of these retained the 4F9 staining although GWB staining was clearly detected (data not shown).

As shown in Fig. 2B, 4F9 staining of GWBs was cell cycle dependent. By costaining with rabbit antiphosphohistone $\mathrm{H} 3$ antibody, 4F9 staining was consistent with the reported staining for GWBs, i.e. larger size during late $\mathrm{S}$ and $\mathrm{G} 2$ phases of the cell cycle and diminished staining during mitosis and G1 (Yang et al., 2004). Since Ago2 is a key component of RISC, the observation that Ago2 staining is cell cycle dependent suggests the possibility that Ago2 and GW182/GWBs may be involved in controlling expression and/or silencing of selected mRNAs involved in the cell cycle (Liu et al., 2005a).

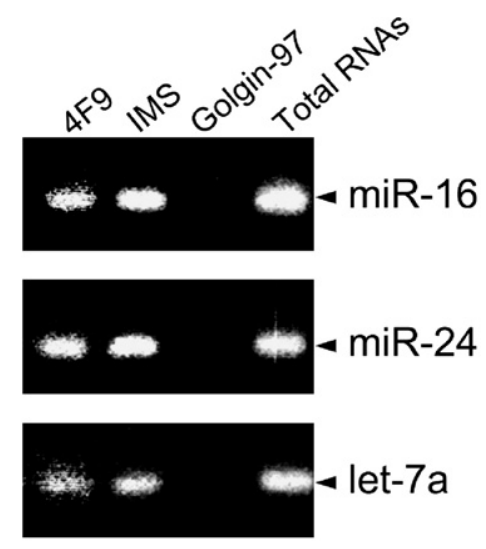

Fig. 4. Argonaute monoclonal antibody captured microRNAs. MicroRNAs were detected in the immunoprecipitates of 4F9 and IMS using RT-PCR. Immunoprecipitates of an unrelated mouse monoclonal anti-golgin-97 were analyzed as a negative control. Total RNAs isolated from human heart were used as a positive control for the RT-PCR. 


\subsection{All Ago proteins could be recognized by $4 F 9$}

Mouse and human anti-Ago2 sera reacted not only with Ago2 but also with Ago1, 3, 4 (Jakymiw et al., 2006). Consequently, we performed IP analysis of 4F9 using in vitro translated Ago proteins. 4F9 immunoprecipitated all Ago proteins as did a mouse anti-Ago2 serum (IMS, Fig. 3). The human Ago proteins have 77.6 to $83.6 \%$ sequence identity with each other (Sasaki et al., 2003) and 4F9 most likely recognizes a shared conformational epitope found in all Ago proteins. In addition, it was previously reported that all 4 Ago proteins localized to GWBs (Liu et al., 2005b). Taken together, we concluded that 4F9 binds all Ago proteins.

\section{5. $4 F 9$ captures miRNAs}

As discussed above, Ago proteins are known to bind miRNAs and we speculated that unless 4F9 binds to the RNA binding domain of Ago proteins and blocks the interaction of miRNA with Ago, the monoclonal antibody may be useful in capturing cellular miRNA bound to Ago proteins. In order to evaluate whether miRNAs are co-precipitated with Ago proteins from HeLa cell extracts, miRNA RT-PCR was performed on the immunoprecipitates of 4F9, mouse anti-Ago 2 serum and an unrelated control mouse monoclonal antibody to the Golgi protein golgin-97. Total RNAs from human heart were used as a positive control for the RT-PCR. After miRNA RT-PCR, microRNA-16 (miR-16), microRNA24 (miR-24) and let-7a were detected in both 4F9 and IMS immunoprecipitates but not in anti-golgin-97 immunoprecipitates (Fig. 4). In addition, a human anti$\mathrm{nRNP} / \mathrm{Sm}$ serum and a human anti-SS-A/Ro serum were used as unrelated antibody control for miRNAs capture and no miRNAs were detected in the immunoprecipitate using these human anti-ribonucleoprotein sera (data not shown). These results are consistent with a previous report that Ago proteins, especially Ago2 protein, and miRNAs form ribonucleoprotein complexes (miRNPs) (Meister et al., 2004). The three miRNAs chosen in this assay have a wide variety of biological functions. miR16 and let-7a regulate tumor necrosis factor- $\alpha$ (Jing et al., 2005) and Ras (Johnson et al., 2005; Akao et al., 2006), respectively, and miR-24 is related to the regulation of cell growth (Cheng et al., 2005).

Among the several hundreds human miRNAs identified to date (Bentwich et al., 2005; Griffiths-Jones et al., 2006), only relatively few have known biological activities. The continuing discovery of novel small RNA such as the class characterized by 26-31 nucleotides and containing "piwi-interacting RNAs", or piRNA, impli- cated in spermatogenesis (Aravin et al., 2006; Girard et al., 2006; Grivna et al., 2006; Lau et al., 2006; Watanabe et al., 2006) will increase the need for improvements in differentiating miRNAs from other small RNAs. In summary, we developed a novel monoclonal antibody 4F9 with the capability of capturing Ago-associated miRNAs in mammalian cells and may help to elucidate their target mRNAs.

\section{Acknowledgements}

This work was supported in part with resources and the use of facilities at the Malcom Randall VA Medical Center, Gainesville, FL, and National Institutes of Health grants AI44074, AI47859, AR07603, AR40391, AR42455, AR44731, AR50661, AR51766, and M01R00082, State of Florida funds to the Center for Autoimmune Diseases, and the Canadian Institutes for Health Research grant MOP-38034. MJF holds the Arthritis Society Chair at the University of Calgary. Linda G. Green and her associates at the UF Hybridoma Core Laboratory are acknowledged for the generation of hybridomas, subcloning, and the generous advice provided.

\section{References}

Akao, Y., Nakagawa, Y., Naoe, T., 2006. let-7 microRNA functions as a potential growth suppressor in human colon cancer cells. Biol. Pharm. Bull. 29, 903.

Aravin, A., Gaidatzis, D., Pfeffer, S., Lagos-Quintana, M., Landgraf, P., Iovino, N., Morris, P., Brownstein, M.J., Kuramochi-Miyagawa, S., Nakano, T., Chien, M., Russo, J.J., Ju, J., Sheridan, R., Sander, C., Zavolan, M., Tuschl, T., in press. A novel class of small RNAs bind to MILI protein in mouse testes. Nature (Electronic publication ahead of print).

Bentwich, I., Avniel, A., Karov, Y., Aharonov, R., Gilad, S., Barad, O., Barzilai, A., Einat, P., Einav, U., Meiri, E., Sharon, E., Spector, Y., Bentwich, Z., 2005. Identification of hundreds of conserved and nonconserved human microRNAs. Nat. Genet. 37, 766.

Carmell, M.A., Xuan, Z., Zhang, M.Q., Hannon, G.J., 2002. The Argonaute family: tentacles that reach into RNAi, developmental control, stem cell maintenance, and tumorigenesis. Genes Dev. 16, 2733.

Cheng, A.M., Byrom, M.W., Shelton, J., Ford, L.P., 2005. Antisense inhibition of human miRNAs and indications for an involvement of miRNA in cell growth and apoptosis. Nucleic Acids Res. 33, 1290.

Eystathioy, T., Chan, E.K.L., Tenenbaum, S.A., Keene, J.D., Griffith, K., Fritzler, M.J., 2002. A phosphorylated cytoplasmic autoantigen, GW182, associates with a unique population of human mRNAs within novel cytoplasmic speckles. Mol. Biol. Cell 13, 1338.

Eystathioy, T., Chan, E.K.L., Takeuchi, K., Mahler, M., Luft, L.M., Zochodne, D.W., Fritzler, M.J., 2003. Clinical and serological associations of autoantibodies to GW bodies and a novel cytoplasmic autoantigen GW182. J. Mol. Med. 81, 811.

Girard, A., Sachidanandam, R., Hannon, G.J., Carmell, M.A., in press. A germline-specific class of small RNAs binds mammalian Piwi proteins. Nature (Electronic publication ahead of print). 
Gregory, R.I., Yan, K.P., Amuthan, G., Chendrimada, T., Doratotaj, B., Cooch, N., Shiekhattar, R., 2004. The Microprocessor complex mediates the genesis of microRNAs. Nature 432, 235.

Griffiths-Jones, S., Grocock, R.J., van Dongen, S., Bateman, A., Enright, A.J., 2006. miRBase: microRNA sequences, targets and gene nomenclature. Nucleic Acids Res. 34, D140.

Grivna, S.T., Beyret, E., Wang, Z., Lin, H., 2006. A novel class of small RNAs in mouse spermatogenic cells. Genes Dev. 20, 1709.

Jakymiw, A., Lian, S., Eystathioy, T., Li, S., Satoh, M., Hamel, J.C., Fritzler, M.J., Chan, E.K.L., 2005. Disruption of GW bodies impairs mammalian RNA interference. Nat. Cell Biol. 7, 1267.

Jakymiw, A., Ikeda, K., Fritzler, M.J., Reeves, W.H., Satoh, M., Chan, E.K.L., 2006. Autoimmune targeting of key components of RNA interference. Arthritis Res. Ther. 8, R87.

Jing, Q., Huang, S., Guth, S., Zarubin, T., Motoyama, A., Chen, J., Di Padova, F., Lin, S.C., Gram, H., Han, J., 2005. Involvement of microRNA in AU-rich element-mediated mRNA instability. Cell 120,623

Johnson, S.M., Grosshans, H., Shingara, J., Byrom, M., Jarvis, R., Cheng, A., Labourier, E., Reinert, K.L., Brown, D., Slack, F.J., 2005. RAS is regulated by the let-7 microRNA family. Cell 120 , 635.

Lau, N.C., Seto, A.G., Kim, J., Kuramochi-Miyagawa, S., Nakano, T., Bartel, D.P., Kingston, R.E., 2006. Characterization of the piRNA Complex from Rat Testes. Science 313, 363.

Liu, J., Rivas, F.V., Wohlschlegel, J., Yates, J.R., Parker, R., Hannon, G.J., 2005a. A role for the P-body component GW182 in microRNA function. Nat. Cell Biol. 7, 1261.

Liu, J., Valencia-Sanchez, M.A., Hannon, G.J., Parker, R., 2005 b. MicroRNA-dependent localization of targeted mRNAs to mammalian P-bodies. Nat. Cell Biol. 7, 719.

Lund, E., Guttinger, S., Calado, A., Dahlberg, J.E., Kutay, U., 2004. Nuclear export of microRNA precursors. Science 303, 95.

Meister, G., Tuschl, T., 2004. Mechanisms of gene silencing by double-stranded RNA. Nature 431, 343.

Meister, G., Landthaler, M., Patkaniowska, A., Dorsett, Y., Teng, G., Tuschl, T., 2004. Human Argonaute2 mediates RNA cleavage targeted by miRNAs and siRNAs. Mol. Cell 15, 185.
Pauley, K.M., Eystathioy, T., Jakymiw, A., Hamel, J.C., Fritzler, M.J., Chan, E.K.L., in press. Formation of GW bodies is a consequence of miRNA genesis EMBO Reports (August 11, Electronic publication ahead of print).

Rubin, R.L., 1997. Enzyme-linked immunosorbent assay for antiDNA and antihistone antibodies including anti-(H2A-H2B). In: Rose, N.R., de Macario, E.C., Folds, J.D., Lane, H.C., Nakamura, R.M. (Eds.), Manual of Clinical Laboratory Immunology. American Society for Microbiology, Washington, D.C., p. 935.

Sasaki, T., Shiohama, A., Minoshima, S., Shimizu, N., 2003. Identification of eight members of the Argonaute family in the human genome small star, filled. Genomics 82, 323.

Satoh, M., Reeves, W.H., 1994. Induction of lupus-associated autoantibodies in BALB/c mice by intraperitoneal injection of pristane. J. Exp. Med. 180, 2341.

Satoh, M., Langdon, J.J., Chou, C.H., McCauliffe, D.P., Treadwell, E.L., Ogasawara, T., Hirakata, M., Suwa, A., Cohen, P.L., Eisenberg, R.A., et al., 1994. Characterization of the Su antigen, a macromolecular complex of $100 / 102$ and $200-\mathrm{kDa}$ proteins recognized by autoantibodies in systemic rheumatic diseases. Clin. Immunol. Immunopathol. 73, 132.

Satoh, M., Treadwell, E.L., Reeves, W.H., 1995. Pristane induces high titers of anti-Su and anti-nRNP/Sm autoantibodies in BALB/c mice. Quantitation by antigen capture ELISAs based on monospecific human autoimmune sera. J. Immunol. Methods 182, 51.

Watanabe, T., Takeda, A., Tsukiyama, T., Mise, K., Okuno, T., Sasaki, H., Minami, N., Imai, H., 2006. Identification and characterization of two novel classes of small RNAs in the mouse germline: retrotransposon-derived siRNAs in oocytes and germline small RNAs in testes. Genes Dev. 20, 1732.

Yang, Z., Jakymiw, A., Wood, M.R., Eystathioy, T., Rubin, R.L., Fritzler, M.J., Chan, E.K.L., 2004. GW182 is critical for the stability of GW bodies expressed during the cell cycle and cell proliferation. J. Cell Sci. 117, 5567. 